\title{
SMOKING AND MUSLIM COUNTRIES: THE IMMEDIATE AND SERIOUS THREAT
}

\author{
by Ahmed Taha
}

M.B. Bch., D.M. M.R.C.P. (U.K.). M.S.C. (L.ond.)

Member, Executive Committee of the Islamic Medical Association of U.K. and Eire

\section{DOI: http://dx.doi.org/10.5915/14-1-12124}

Cigarette smoking is the major environmental cause of death in Western countries. At least 50.000 men and women in U.K. die from its effects every year. Lung cancer and heart attack are the two important diseases catused by smoking. In the United States lung cancer death rates have increased fivefold between 1945 and 1975. and in women are expected to exceed those for other cancers in the next decade. In U.K. about a yuarter of 40.000 deaths in men and women under 65 who die each year from heart attack are believed to be due to cigarette smoking. and 90 percent of 37,000 deaths from lung cancer each year can be attributed to cigarette smoking. In 1974 it was estimated that about f 400 million was spent in U.K. on the cost of treatment. sickness and loss of production time from work as a result of smoking related diseases.

The risks of smoking are not confined to Western nations. Cigarette consumption is rapidly increasing in many Muslim countries, whose population is the target of promotional drives by cigarette manufacturers, and smoking threatens to become one of tomorrow's major health hazards. Hopefully Muslim countries will study the consequences of cigarette smoking in the West and will act before these diseases press too heavily upon them and stretch their resources for health care.

\section{Cigarette Consumption and Promotion}

Smoking is becoming a common and widely accepted social habit in Muslim countries. especially amongst the children and adolescents. One half of the population of Turkey is considered to be smokers. ${ }^{1}$ In Nigeria more than a third of men and 40 percent of boys in secondary schools in one big city were found to smoke.2 A survey conducted in four villages in Malaysia showed that 56 percent of men and 20 percent of women were regular smokers. The prevalence of smoking is higher in urban than in rural areas. where only men used to smoke, but the proportion of women who smoke is now rising as in Egypt. In Senegal 80 percent of urban men. but only IS percent of rural men smoke cigarettes, ${ }^{4}$ Cigarette consumption in most Muslim countries rose steeply in the last years. In Egypt, the Eastern Tobacco Company's cigarette sales increased by 23 percent between 1976-78, and imported cigarette sales went by 25 percent between 1977-78.5 Cigarette consumption in Libya doubled between 1967 and 1976..$^{\circ}$ (Fig.). The world's largest airlift of cigarettes is operated from Britain to Sudan and Somalia. About 210 tons of cigarettes are carried every month to both countries.

Not only do individuals become dependent on cigarettes but so does the economy of a country either 
by expanding its growth or by relying on its taxation for revenue. Several Muslim countries plan to expand tobacco growth so that they can supply their own needs and also export tobacco. Pakistan. Iran and Iraq are the main producers. Altogether. in 1970 they produced 152.000 metric tons of tobacco (one metric ton produces one million cigarettes) ${ }^{*}$ In contrast Egypt does not grow tobacco, but has one of the latgest manufacturing industries in the world, using 100 percent imported tobacco. The volume of tobacco exported by Indonesia almost doubled between 1972 and $1977.7^{4}$

Cigarettes are heavily promoted in many Muslim countries. There is a widespread advertising of cigarettes on posters. television. radio and in newspapers. A study of cigarette marketing in Malaysia showed heavy tobacco advertising and an efficient distribution of cigarettes in all parts of the country including rural areas. ${ }^{9}$ In most Muslim countries advertisement is quite liberal and more aggressive than in the West. presenting smoking as a socially desirable habit and relating it to success in life. No health warning is carried on cigarette packs and in most Muslim countries health education about the effects of smoking has hardly begun.

\section{Cigarette-Associated Diseases}

Smoking is "probably the largest single preventable cause of ill-health in the world". At present diseases of infection and malnutrition are the main cause of death in Muslim countries and unless rapid action is taken to control smoking, diseases due to smoking will soon be added to the burden of those of infection and malnutrition. A review of smoking-associated diseases in Muslim countries shows that these diseases are already making their appearance. The lung cancer rate has increased three-fold in the last 30 years in Egypt." In a survey of 1.400 patients with heart disease in Iran, 98 percent were smokers. ${ }^{12}$ Smokers in Muslim countries are probably at a higher risk compared to those in the Western countries. There is evidence that cigarettes sold in developing countries may contain twice as much tar and nicotine as the same named brands in Europe. Tar and nicotine are the substances that cause lung cancer and heart disease respectively.

\section{Islam and Smoking}

The evidence relating cigarette smoking to disease appeared nearly 20 years ago. For this reason Muslim schotars in the past differed in opinion regarding smoking. One group considered it haram, another group said it is makrooh. and a third one said it is haram only for those who know by experience or have been told by a trustworthy doctor that smoking is harmful to them. Smoking is considered haram for the following reasons: $:^{13}$ i) It is now evident beyond doubt that smoking damages health and Allah says:

$$
\text { "ولا تلقوا بايد يكم الى التشلكة" }
$$

"And make not your own hands contribute to your destruction"

Al-Baqarah: 195

"ولا تقتلوا انفسكم ان الله كان بكم رحيما "

"Nor kill or destroy yourselves: for verily Allah hath been to you most Merciful"

An-Nisa: 29

and the Prophet (peace be upon him) says:

$$
\text { "لا فر ولا نسرار " }
$$

"Nor be hurted or injure others"

ii) Smokers waste their money and Allah says:

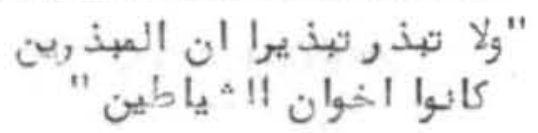

"But squander not your wealth in the manner of a spendthrift, verily spendthrifts are brothers of evils"

$$
\text { Al-Isra: 26, } 27
$$

and the Prophet peace be upon him says that Allah hates for Muslims to waste their money.

iii) In all aspects, cigarettes are an evil. Smokers smell bad and they irritate non-smokers and Allah says:

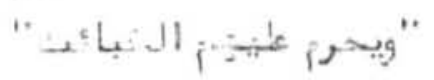

"And forbids them what is bad"

$$
\text { Al-Araf: } 157
$$

\section{Control of Smoking in Muslim Countries}

Control of smoking is one of the major problems facing many countries. Muslim communities need to change public opinion on smoking. The short term economic benefits of tobacco are out-weighed by the long term disadvantages: therefore governments of Muslim countries have to avoid dependence on the growth of tobacco which may do little for long term prosperity and can only lead to disaster. No-smoking should be the normal behaviour in Muslim society which makes it easier for individual to stop smoking. Muslim doctors have a special responsibility - by their own example, by the advice they give to other people and by the collective advice they give their government through their responsible medical bodies. They should refrain from smoking as an Islamic obligation.

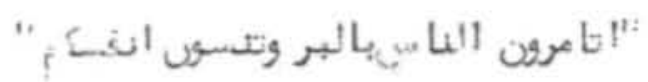


"Do ye enjoin right conduct on the people and forget to practice it yourselves."

They also have to urge their government to introduce legislative measures to control smoking in Muslim countries. These include a ban on advertising and other forms of promotions, health warning in the native languages on all cigarette packs, a ban on smoking in public places and restriction on the sale of cigarettes to children. Governments should also be urged to consider health education programmes concerning smoking as a part of the general education and to change their policy on tobacco growing, which should be phased out and food crops substituted wherever possible. Special attention should be given to children at primary and secondary schools where most smokers start the smoking habit. Preventive measures taken now could do much to improve the health of the next Muslim generation.

\section{REFERENCES}

1. Banjamin, B., Tobacco Smoking in the World. WHO Expert Committee on Smoking Control. CVD/S/78.23.

2. Elegbeleye, O.O. \& Femi-Pearse, D.. Incidence and Variable Contributing to Onset of Cigarette Smoking among Secondary and Medical Students in Lagos-Nigeria. British Journal of Preventive and Social Medicine. 1976; 30:66-70.
3. Pathmanathan, 1., Tobacco Smoking Pattern in a Rural Community in Negari Sembilan (Malaya). Medical Journal of Malaysia. 1974: 29: 34-9.

4. Baylet, Retal. Enquetes sur I'utilisation centres coutumiers et en milieu urbanise au Senegal. Bull. Soc. Med. Afr. Noire Lnaq. Fr. 1974. 19. 36-40.

5. Sherif Omar. Personal Communication.

6. Maxwell, International Estimates in World Tobacco.

7. Anonymous, U.K. Tobacco: a Tough Year Ahead. Tobacco Reporter. 1980: 107:42-3.

8. Rao K.S. (1976) Special Nature of Tobacco Problem in Eastern Mediterranean Region. WHO Cyclostyled.

9. Saroso, J.S., Comment on Smoking and Health. WHO Expert Committee of Smoking Control. CVD/S/EC/98.29.

10 Wickstrom, B.O., Cigarette Marketing and Third World. Gothenberg. Sweden. University of Gothenberg, 1979.

11. Mahfouz, M.M., Smoking in Egypt, WHO Expert Committee on Smoking and Effect on Health. NCD/EC/74.22.

12. Sadaghi, A., Gharavi, M.. \& Harandi Zach. R.. A Letter, South African Medical Journal, 1975: 49:767.

13. Yusuf Al Qaradawi, Al Halal wal Haram. Cairo, 1960.

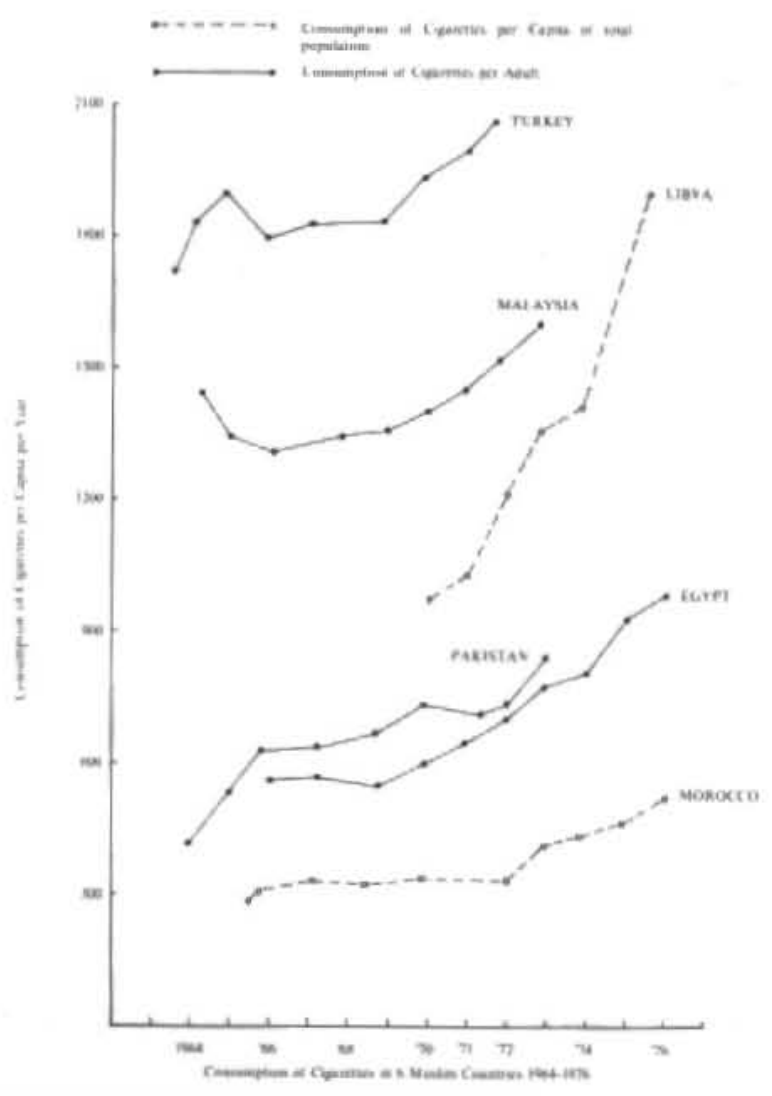

